\title{
FOUR NEW BRACHIOPOD GENERA OF THE SUBFAMILY OEPIKINAE (STROPHOMENACEA) FROM THE ORDOVICIAN OF ESTONIA
}

Abstract. Four new genera, Panderites, Tallinnites, Bekkerina (with one new species), and Geniculina are described. Panderites sp. from the Kunda Stage is the earliest representative of Oepikinae in the Ordovician of Baltoscandia. Bekkerina include species heretofore usually assigned to the genus Oepikina.

The earliest Ordovician strophomenaceans in Estonia belong to the subfamily Oepikinae, first erected by Sokolskaya (Сокольская, 1960, p. 211) as a subfamily Oepikinae, and later promoted to the familial rank by Pope $(1976$, p. 148). The original diagnosis of Sokolskaya is as follows: "Small, strongly convex, geniculate, without concentric rugae on the visceral disc. Elements of the interior sharply developed. Pseudopunctae very fine, dense." Williams (1965, p. 388) presented an emended diagnosis for the subfamily Oepikinae. This diagnosis is acceptable, except that posterolateral impersistent rugae are hardly common within the group. Factually oblique wrinkles occur only in the new genera Tallinnites and Geniculina, and on some species of Oepikina, described by Cooper (1956). However, the taxonomical significance of the precence of the wrinkles as well as that of the denticulated socket plates is not yet clear.

The study of the Estonian oepikins has shown that the generic content of the subfamily Oepikinae is greater than hitherto presumed. In this paper the new genera Panderites, Tallinnites, Bekkerina, and Geniculina are erected. Besides, the genera Oslomena and Dactylogonia probably occur in the upper part of the Viru Series of Estonia.

In North Estonia several strophomenacean genera such as Septomena and Estonomena among leptaenins, Actinomena among strophomenids, and Tallinnites and Bekkerina among oepikins appear in the Lasnamägi and Uhaku stages (U. Llanvirn and Llandeilo). The earliest known strophomenacean is Panderites, which occurs already in the uppermost part of the Kunda Stage (L. Llanvirn). The existence of many related strophomenacean genera in the Ordovician basin of Baltoscandia probably indicates that this basin may have been a centre of development and radiation of this superfamily (Rõõmusoks, 1989).

The types and illustrated specimens of the new genera are housed in the Museum of Geology of Tartu University ( $\mathrm{Br}$ marks the brachiopod types catalogue number).

* Tartu Ulikooli Geoloogia Instituut (Institute of Geology, University of Tartu), Vanemuise 46, EE-2400 Tartu. Estonia. 
Derivation of name. After Christian Pander.

Type species. Plectambonites imbrex Pander, 1830 from the Aseri Stage (U. Llanvirn) of Ingria (St. Petersburg area), in Russia.

Diagnosis: Medium-size Oepikinae (known maximum width of the interarea $22 \mathrm{~mm}$ ) with concavo-convex shell at right angle geniculated in dorsal direction. Disc in both valves almost flat. Trail more than twice longer than disc. Ornament unequally parvicostellate, strongly filate, 10-12 relatively thin, accentuated costellae which have very broad interspaces. Pseudodeltidium small, apical; chilidium large. Cardinal process lobes small, inclined towards hinge line. Posterior platform broad, low, with broad low medial ridge. Long, thin breviseptum. Two pairs of short thin, diverging transmuscle septa. Ventral muscle field subcircular, faintly impressed, without bounding ridges. Shell substance very finely and densely pseudopunctate.

Distribution. Ontika Subseries, Kunda Stage (L. Llanvirn) to lower part of the Viru Series, Aseri Stage (U. Llanvirn) of North Estonia; Ingria, Russia. The earliest specimen of Panderites for Estonia, probably a new species, was collected by V. Jaanusson in 1940 from the upper part of the Kunda Stage (Aluoja Substage) at Mäeküla near Tallinn. In Ingria $P$. imbrex was reported to occur already in the lowermost Kunda Stage (Lamansky, 1905 , pp. 57, 59, 76). Thus Panderites is the earliest Baltoscandian oepikin known.

\section{Panderites imbrex (Pander)}

Pl. I, figs. $1-5$

1830 Plectambonites imbrex Pander p. 91; pl. XIX, fig. 12.

1830 Plectambonites triangularis Pander p. 91; Pl. XIX, fig. 11.

1954 Oepikina imbrex (Pander) in Сокольская, p. 48; Pl. II, figs. $5-8$, non fig. 9 .

Neotype (selected here). Complete shell ( $\mathrm{Br}$ 1583) from the Aseri Stage (U. Llanvirn) at Pavlovsk, Ingria, Russia.

Diagnosis: as for the genus.

Remarks. Pander's original collection has got lost (see Lamansky, 1905, p. 24; Ópik, 1930, p. 119); therefore, it seems to be suitable to select here a neotype from topotype specimens. Pander has not named the locality of the illustrated specimens, but he mentioned in the text that his material was collected in several localities, among them Pavlovsk. Apart from Pander's paper the true imbrex from exposures at the Volhov River (east from St. Petersburg) has been described and illustrated only by Sokolskaya (Сокольская, 1954). All other forms named by different authors as imbrex are not conspecific (see Opik, 1930, p. 196). The interiors of $P$. imbrex have never been illustrated before.

Discussion. Panderites differ from all other oepikins known possessing strong geniculation at right angle, long trail and peculiar ornament. Dorsal interior is most similar to Bekkerina, its probable successor. 
Derivation of name. After Tallinn, the capital of Estonia, where good exposures of the Lasnamägi and Uhaku stages are located.

Type species. Oepikina (?) imbrexoidea Sokolskaya (Сокольская, 1954, p. 51; P1. II, figs. 11-13, text-fig. 14) from the Uhaku Stage, Kõrgekallas Formation (Llandeilo) of North Estonia (see P1. II, figs. 1-4 in the present article).

Diagnosis: Medium-size Oepikinae (known maximum length of the shell $30 \mathrm{~mm}$ ) with shells subrectangular in outline; the length exceeds slightly the width; anterior margin broadly rounded. Ventral valve evenly and strongly convex in both profiles, dorsal valve correspondingly concave. The ornament unequally parvicostellate with relatively broad interspaces between accentuated costellae and 4-6 finer costellae between them on medial part of the shell near anterior margin. Short weak wrinkles posterolaterally. Pseudodeltidium small, apical; chilidium large, broad. Ventral muscle field long, elliptic with strong anteriorly converging bounding ridges and a medial ridge. The posterior platform narrow, with long medial ridge and broad, weakly developed low lateral ridges bearing very short, broad socket plates. Anterior pair of transmuscle septa high, thin, short, subparallel to medial ridge. Posterior pair long, high, anteriorly divergent. Long breviseptum. The shell structure finely and densely pseudopunctate.

Discussion. The type species was described and illustrated by Öpik (1930, p. 196; P1. XXI, fig. 272) as Rafinesquina aff. imbrex (Pander) and Sokolskaya (Сокольская, 1954, p. 51; Pl. II, figs. 10-13, text-fig. 14) based on the exterior character only. Now I have some excellent interiors that indicate a Bekkerina-like internal structure of the dorsal valve but a very different ventral one. Ornament, weak posterolateral wrinkles, and ventral interior resemble those of the younger genus Geniculina, except for the socket plates, which are gently developed and do not bear denticles. The ancestor of Tallinnites is not known. Characteristics of the interior, ornament, and strong evenly convex, not geniculate, ventral valve are the best distinguishing features for the new genus.

Distribution. Viru Series of North Estonia; Ingria, Russia, Lasnamägi Stage (U. Llanvirn) and Uhaku Stage, Väo and Kõrgekallas formations (Llandeilo) (Pygodus serrus and P. anserinus Conodont Zones of Bergström, 1971).

\section{Genus Bekkerina nov.}

Derivation of name. After Hendrik Bekker, the first Estonian professor of geology at Tartu University.

Type species. Rafinesquina dorsata Bekker, 1921, p. 73; P1. III, figs. 913; Pl. V, figs $4-8$ from the Kukruse Stage.

Diagnosis: Small Oepikinae (known maximum width of the interarea $20 \mathrm{~mm}$ ) with suboval to rounded-trapezoidal shell, widest in the middle. Ventral valve strongly convex, evenly geniculated, with small hemispherical disc. No posterolateral oblique wrinkles. Dorsal valve strongly concave. Radial ornament clearly unequally parvicostellate, commonly with many accentuated costellae. Pseudodeltidium vestigial or absent; 
chilidium small, medially weakly grooved. Interareas small. Ventral muscle field impressed, very large, occupying more than half of the interior, radially striated, without raised bounding ridges. There is a long narrow medial ridge. Teeth crenulate. Cardinal process lobes high, stout, posteriorly inclined. They have a deep groove for muscle attachment on the posterior side. Laterally from the base of cardinal process to posterior part of subperipheral rim extends a pair of wide, high and long ridges bearing thin, long socket plates. Anterior transmuscle septa mostly high and long. Subperipheral rim well developed, interrupted by short vascular markings. The shell structure finely and densely pseudopunctate.

\section{Species assigned}

Rafinesquina dorsata Bekker, 1921, p. 73 (see Pl. I, fig. 10; P1. II, figs. $5-10$ in the present article) from the Kukruse Stage, Viivikonna Formation, North Estonia; Ingria, St. Petersburg area, Russia.

Rafinesquina jaervensis Bekker, 1921, p. 75; Pl. I, fig. 23; Pl. III, figs. 5-8 from the Kukruse Stage, Viivikonna Formation (Llandeilo), North Estonia.

Rafinesquina angusta Öpik (Öpik, 1930, p. 194; P1. XV, fig. 177) from uppermost Kukruse Stage, Peetri Member of the Viivikonna Formation (L. Caradoc?), NW Estonia.

Oepikina dorsata var. assatkini Alichova (Алихова, 1951, р. 51; Pl. IV, fig. 64; see P1. III, figs. $1-4$ in the present paper). From the Idavere Stage, Vasavere Formation (L. Caradoc), North Estonia; Ingria, Russia.

Bekkerina raricostellata sp. n., Pl. I, figs. 6-9. Derivation of name. From Latin rarus, sparse, referring to the few accentuated costellae.

Holotype. Complete shell ( $\mathrm{Br}$ 1579) from the Uhaku Stage. Koljala Member of the Kõrgekallas Formation (Llandeilo), Kiviõli-Erra ditch, $200 \mathrm{~m}$ north of the road, coll. author, 1964. Diagnosis: Small Bekkerina (maximum known width of the interarea $11 \mathrm{~mm}$ ). Ornament with few accentuated costellae. Dorsal transmuscle septa short, low. Remarks. $B$. raricostellata is the earliest Bekkerina species in the Ordovician of Estonia and differs from all the other species of that genus in the character of the radial ornament. In this respect it somewhat resembles Panderites from the underlying Aseri Stage, but otherwise it is a typical Bekkerina.

Distribution. Lasnamägi (?) and Uhaku stages. Väo and Kõrgekallas formations (U. Llanvirn-L. Llandeilo), North Estonia.

Discussion. Salmon (1942, p. 589) erected the genus Oepikina. In the course of that study Opik sent her 18 specimens of $R$. dorsata from the Kukruse Stage. She described this species too and included it in her new genus (Salmon, 1942, p. 592). Salmon noted: "In the brachial valve, the septa are more high and thin, and the anterior pair is curved inward at the posterior end and outward at the anterior. The only American species that resembles $\ddot{O}$. dorsata is $\ddot{O}$. minnesotensis (Winchell). The latter is somewhat larger and, although highly convex, has a definite geniculation and a long strait slope in the anterior portion, so that its lateral aspect is quite different."

Salmon's opinion regarding the inclusion of the $R$. dorsata group of species to Oepikina has been followed by all subsequent authors (Алихова, 1951, 1953; Сокольская, 1954, 1960; Spjeldnaes, 1957; Андреева, 1961). Cooper (1956) described numerous new species of Oepikina from North American lower Middle Ordovician. It seems to me that this genus is in his interpretation somewhat heterogeneous - representatives of several genera may perhaps be included. 
I have studied the originals of Bekker and Opik as well as new material in our collections, and I am sure that a new genus should be erected for the Baltoscandian species. However, two species formerly included in Oepikina, Rafinesquina anijana Öpik (1930, p. 197) and Oepikina anijana grandis Alichova (Алихова, 1953, р. 115), probably belong to Oslomena Spjeldnaes, 1957.

Bekkerina includes the smallest oepikins known. This genus differs from North American Oepikina in having smaller shells with greater convexity, more highly developed transmuscle septa, particularly anterior ones, which are usually anteriorly curved outwards, and a distinctive cardinalia. The relatively high, long ridges, bearing socket plates are fused to the posterior ends of the subperipheral rim.

Bekker and Opik described some additional species and subspecies, such as Rafinesquina imbrex (Pander) sensu Bekker, 1921, p. 72; R. dorsata media Opik, 1930, p. 189 (non Oepikina dorsata media Opik in Spjeldnaes, 1957, p. 169 = Oslomena), R. bekkeri Opik, 1930, p. 190; R. troedssoni Opik, 1930, p. 195 (only two pathological specimens known) - all from the lower part of the Kukruse Stage, Kiviõli Member. Examination of the types of these species and subspecies has shown that these taxa fall into the intraspecific variation of $B$. dorsata.

Distribution. Viru Series of Baltoscandia. The Lasnamägi? and Uhaku stages (U. Llanvirn-L. Llandeilo), the Kukruse Stage (U. Llandeilo) and Idavere Stage, Vasavere Formation (L. Caradoc); (Eoplacognathus foliaceus Subzone of the Pygodus serrus Zone to Prioniodus gerdae Subzone of the Amorphognathus tvaerensis Conodont Zone), North Estonia; Ingria, Russia; Northern Oland (Lower Dalby Limestone; Oepikina cf. dorsata in Jaanusson, 1960, p. 230).

\section{PLATE I}

Figs. 1-5. Panderites imbrex (Pander), all from Aseri Stage. $1-3-$ posterior and lateral views $(\times 2)$, sculpture $(\times 3)$ of complete shell, neotype $(\mathrm{Br} 1583)$; Pavlovsk, Ingria, St. Petersburg area, Russia, old collection. 4 - dorsal interior $(\times 2)$ (Naturhistoriska Riksmuseet, $\mathrm{Br}$ 131660). Popovka, Ingria, 5 - ventral interior $(\times 2,5)$ (Br 1625). Pavlovsk, Ingria. Figs. 6-9. Bekkerina raricostellata sp. n., all from Uhaku Stage, North Estonia. 6 - dorsal interior $(\times 4)(\mathrm{Br} 1580)$. Harku, coll. author, 1951. $7-8$ - posterior and lateral views of complete shell, holotype $(\times 4)(\mathrm{Br} 1579)$. KiviōliErra ditch, coll. author, 1964. 9 - ventral interior $(\times 4)(\mathrm{Br} 1581)$. Lasnamägi, coll. author, 1949. Fig. 10. Bekkerina dorsata (Bekker) from Kukruse Stage, Kohtla. Ventral interior (X4) Br 236 (168). Kohtla (Öpik, 1930, pl. XV, fig. 168).

\section{PLATE II}

Figs. 1-4. Tallinnites imbrexoideus (Sokolskaya), all from Uhaku Stage. 1-2 ventral and lateral views of complete shell $(\times 2)(\mathrm{Br} 1572)$. Kohtla-Järve, coll. author, 1966. 3 - ventral interior $(\times 2,5) \quad(B r 1617)$. Loo, coll. R. Usar, 1953. 4 - dorsal interior $(\times 2)(\mathrm{Br} 1574)$. Lasnamägi, coll. author and V. Nurm, 1949. Figs. 5-10. Bekkerina dorsata (Bekker), all from Kukruse Stage. $5-8$ - posterior $(\times 4)$, lateral $(\times 3)$, anterior $(\times 3,6)$ and dorsal $(\times 4)$ views of complete shell $\mathrm{Br} 227$ (160). Kohtla. Opik (1930, pl. XIV, fig. 160). 9-10-dorsal and posterior views $(\times 3,6) \operatorname{Br} 229$ (276). Kohtla. Opik (1930, p. 184, text-fig. 22). 
PLATE I
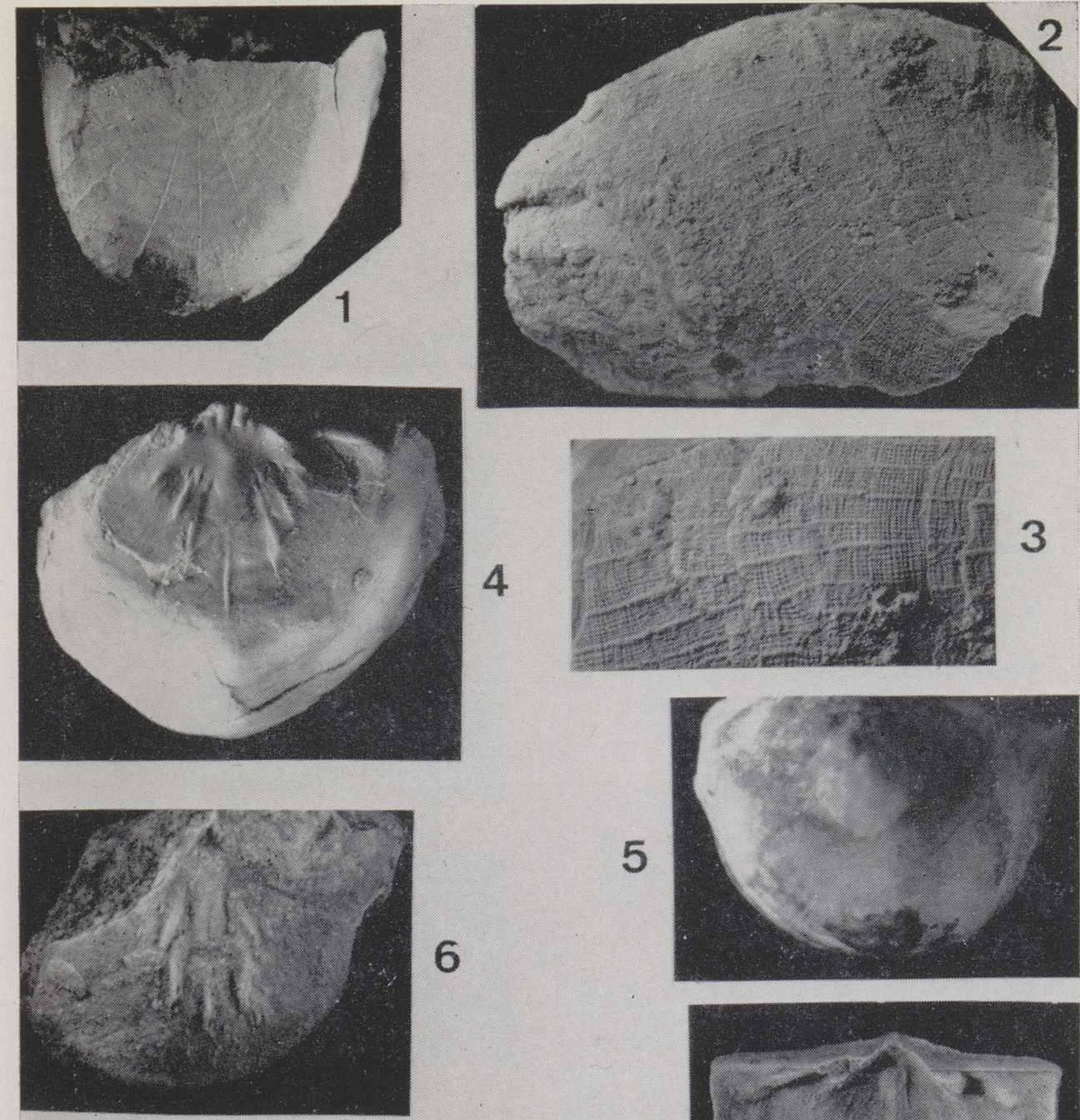

6

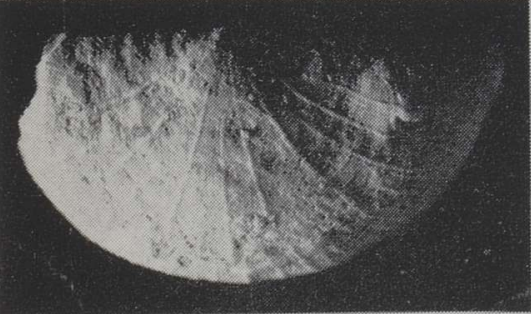

4

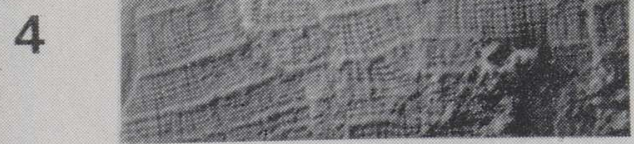

3
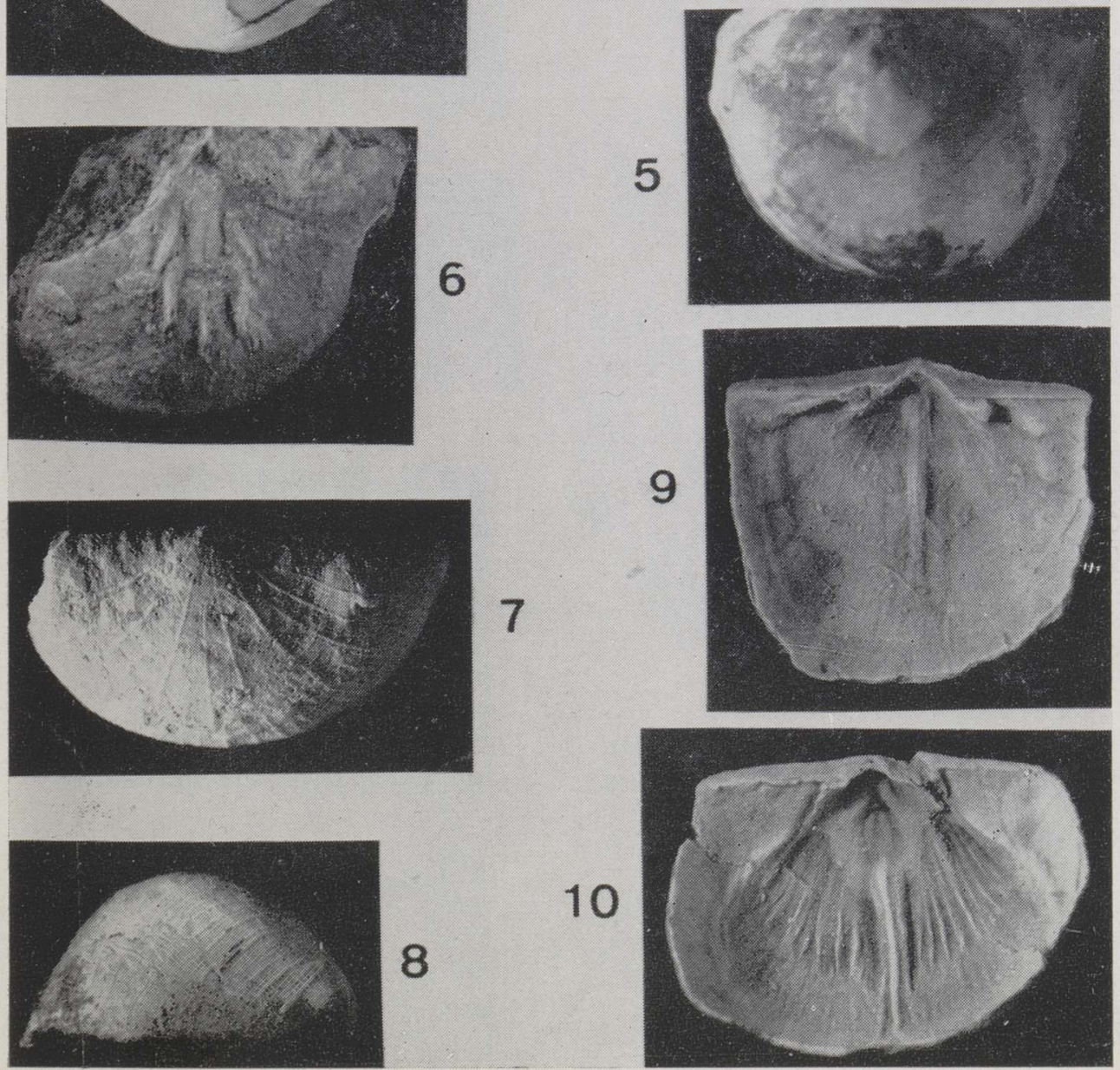

8

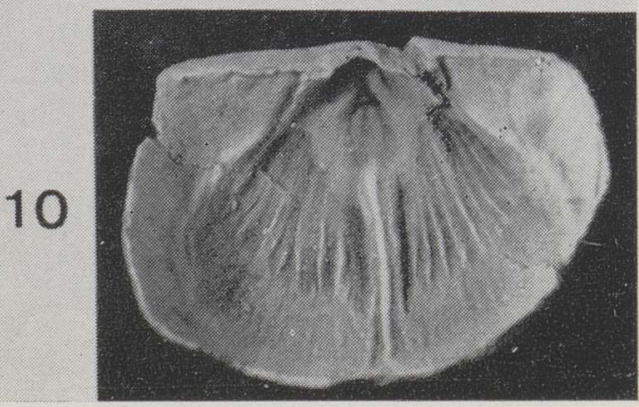


PLATE II
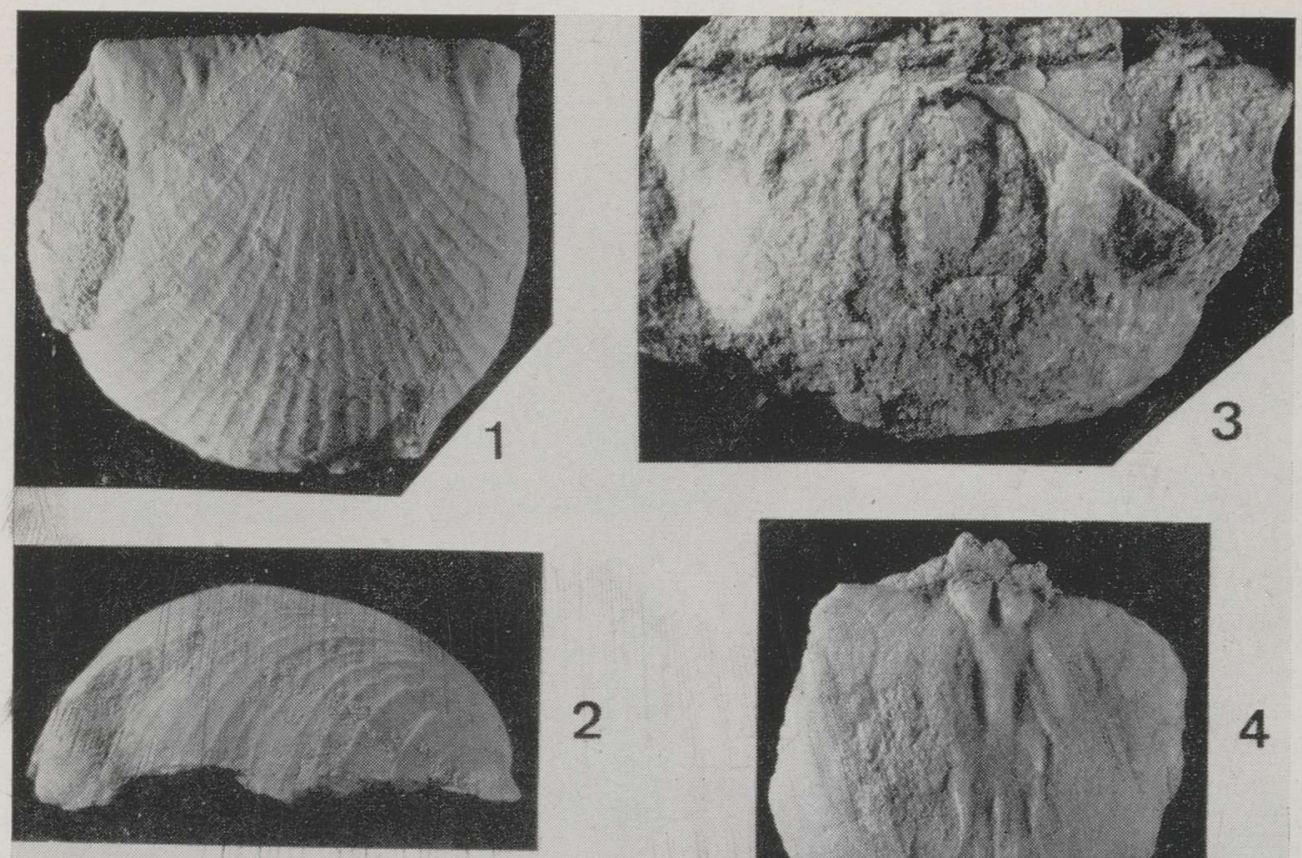

2
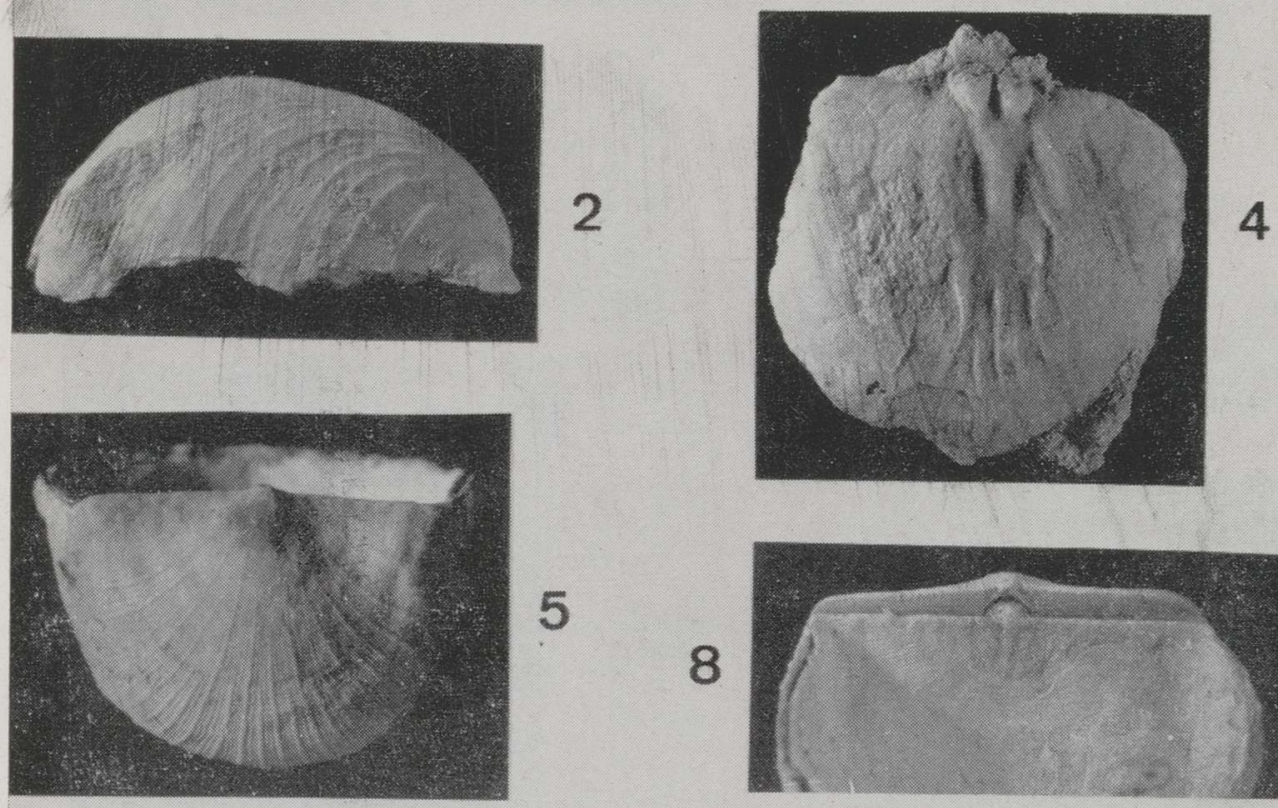

5

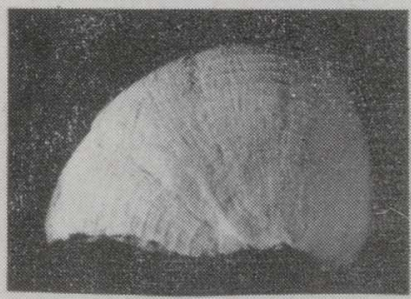

6
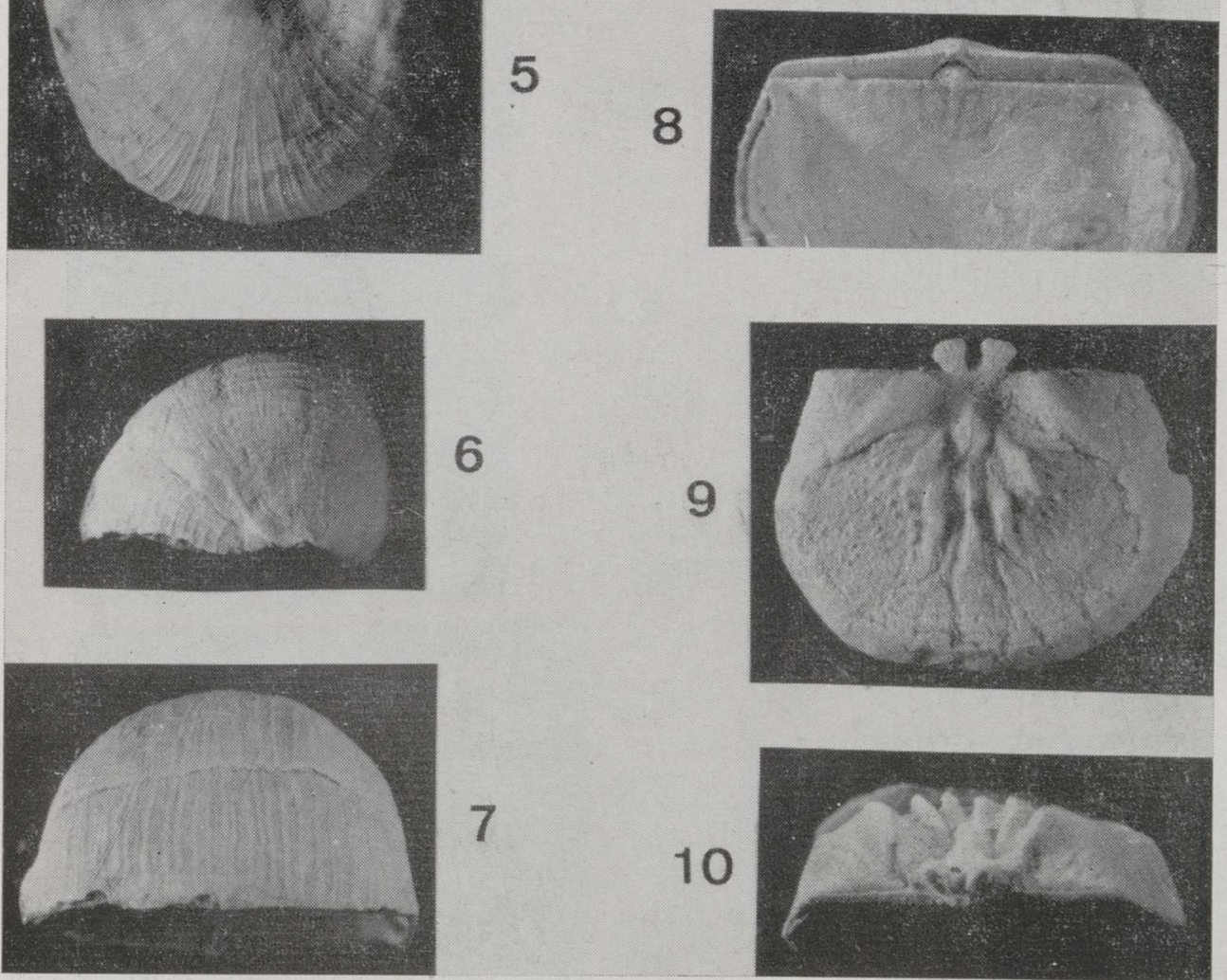

7
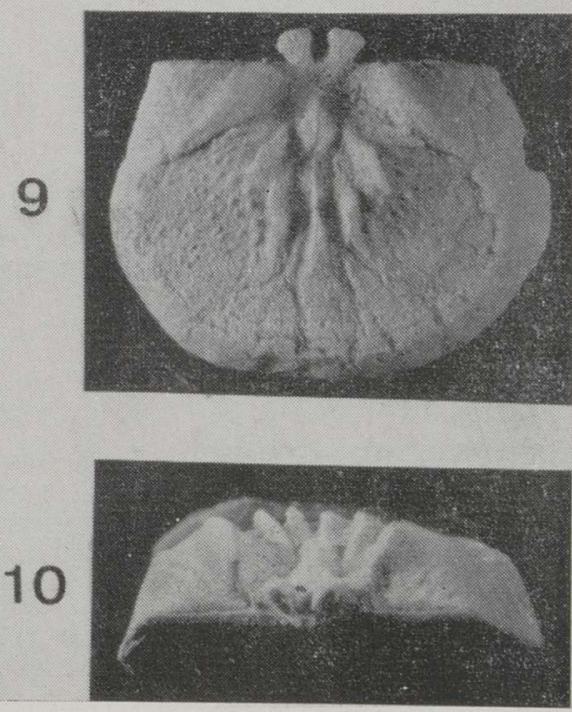
PLATE IV
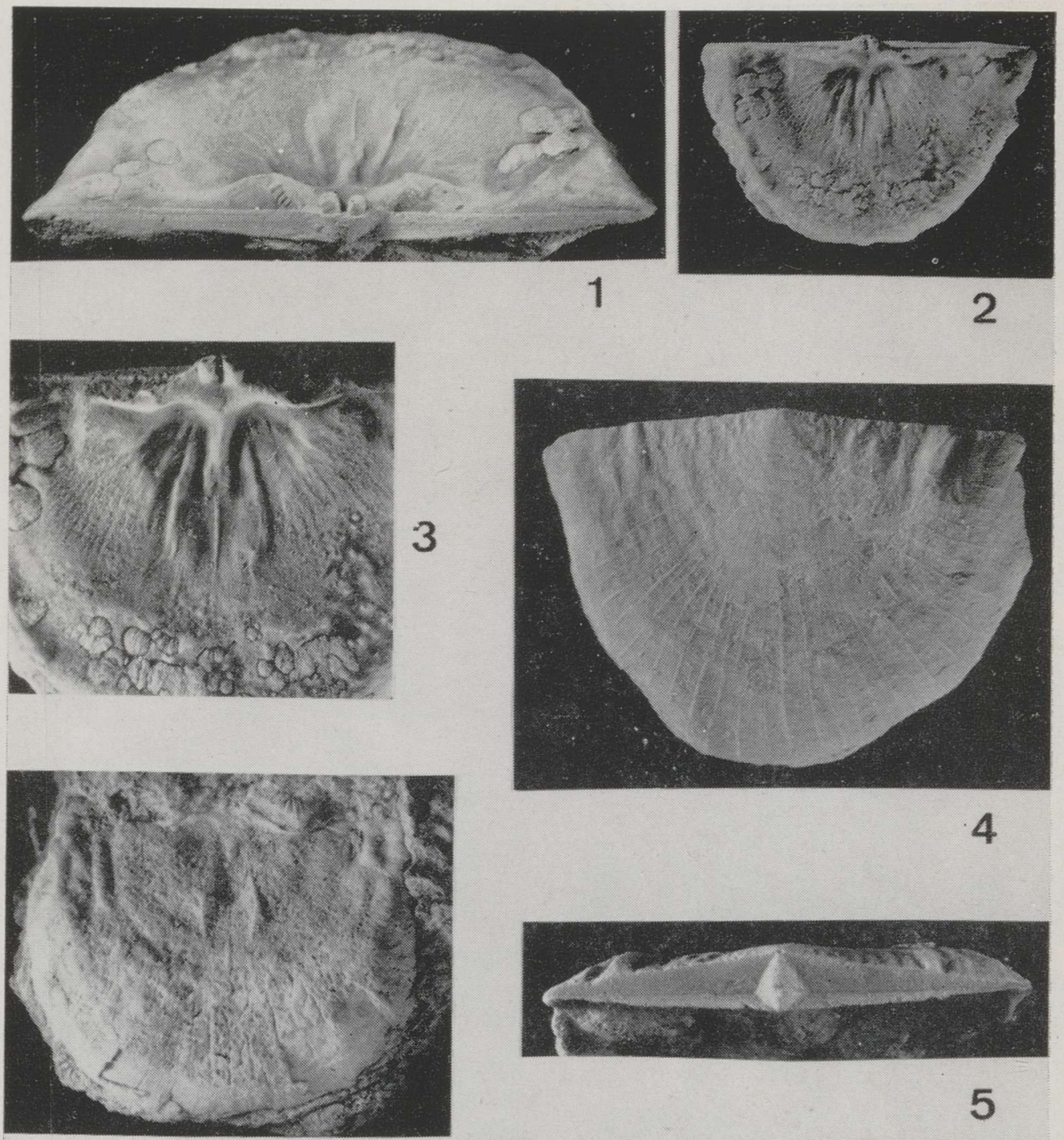

4

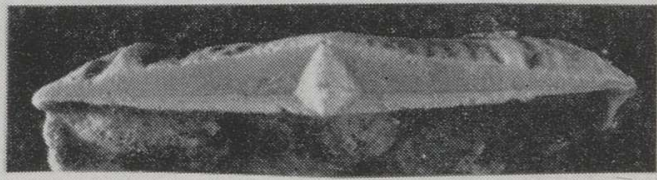

5

7

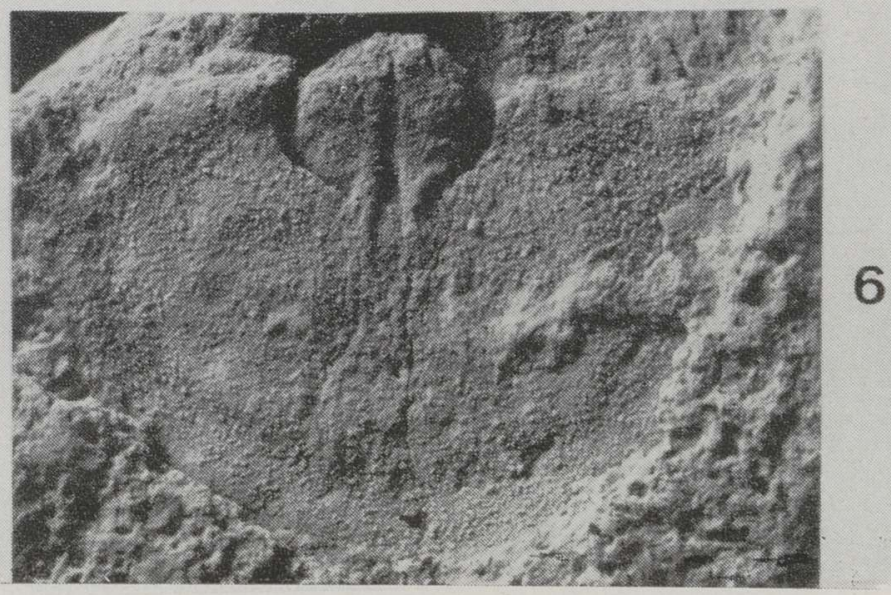



tion.

Derivation of name. From Latin, genu, knee, referring to the genicula-

Type species. Strophomena pseudoalternata Schmidt 1858, p. 214 from the Pirgu Stage, Adila Formation with Röa Member ( $M$. Ashgill) of North Estonia.

Diagnosis: Medium-size to large Oepikinae (maximum known width of the interarea $38 \mathrm{~mm}$ ) with concavo-convex suboval strongly geniculated shell. Widest at the hinge line. Disc in both valves almost flat. The trail longer than the disc. The ornament strongly unequally parvicostellate. Short, irregular, usually oblique wrinkles posterolaterally. Large pseudodeltidium and chilidium, almost equal in size, the latter medially grooved. Ventral muscle field large, subcircular or rhomboidal with sharply raised bounding ridges and a medial ridge. The posterior platform short, socket plates with small denticles. Anterior pair of transmuscle septa thin and long; posterior pair weakly developed or absent. Long thin breviseptum. Well-developed, high and long subperipheral rim. The shell structure very finely and densely pseudopunctate.

\section{Species assigned}

Oepikina (?) subaequiclina Alichova (Алихова, 1951, p. 57; P1. IV, figs. 72,73 ) (see P1. III, figs. 5-9 in the present paper) from the Rakvere Stage (L. Ashgill ?), North Estonia; St. Petersburg area, Russia.

Oepikina limbrata Wang, 1949, p. 22; P1. 6, figs. $1-7$ from the L. Maquoketa Shale, Clermont, Iowa, USA. I had the opportunity to examine specimens of this species in the collections of the Swedish Museum of Natural History, Stockholm, in 1991. Similar species are "Rafinesquina" pergibbosa Foerste, 1917 from North Michigan and "Rafinesquina" altidorsata Bradley, 1921 from Iowa. Unfortunately the ventral interior of these two species is not known, and the generic assignment remains somewhat unclear. The problem is discussed in detail by Macomber (1970, p. 441-442), who gives some good illustrations (except the interior of the ventral valve) of "Oepikina" cf. O. pergibbosa from the U. Bighorn Formation of Wyoming.

\section{PLATE III}

Figs. 1-4. Bekkerina assatkini (Alichova), all from Idavere Stage, Vasavere Formation. $1-2$ - ventral and posterior views of complete shell $(\times 3)(\mathrm{Br} 1584)$. Aluvere, coll. A. Öpik. 3 - dorsal interior $(\times 3)(\mathrm{Br} 1585)$, Aluvere, coll. A. Öpik. 4 - ventral interior $(\times 3)(\mathrm{Br} 1586)$. Aluvere, coll. author, 1962. Figs. 5-10. Geniculina subaequiclina (Alichova), all from Rakvere Stage, Rägavere Formation, at Rakvere. 5-7 - ventral, dorsal, and posterior views $(\times 2)(\mathrm{Br} 1543)$; coll. H. Palmre, 1937. 8 - dorsal interior ( $\times 2)(\mathrm{Br}$ 1558), coll. G. Mechmershausen, 1920. 9-10 - ventral interiors $(\mathrm{Br} 1556)$ and $(\mathrm{Br} 1557)(\times 2,2$ and $\times 2)$, coll. G. Mechmershausen, 1920 .

\section{$+i$ PLATE IV}

Figs. 1-6. Geniculina pseudoalternata (Schmidt), all from Pirgu Stage, Adila Formation. $1-3-$ dorsal interior views of lectotype $(\times 2, \times 1,2, \times 2)(\mathrm{Br} 1460)$. Vardi, coll. Fr. Schmidt. 4-5 - dorsal and posterior views $(\times 2)(\mathrm{Br}, 1463)$. Piirsalu, coll. Fr. Schmidt. 6 - ventral interior mould $(\times 2)(\mathrm{Br} 1539)$. Röa, coll. author, 1975. Fig. 7 - Geniculina sp. n., dorsal interior ( $\times 1,9)$ (Naturhistoriska Riksmuseet $\mathrm{Br} 6753$ ), Osmundsberget, Dalarna, Boda Limestone. 
1858 Strophomena pseudoalternata Schmidt, p. 214.

non 1916 Rafinesquina pseudoalternata Schmidt, in Holtedahl, p. 21; P1. III, figs. 9-11 (= Geniculina sp. n.).

1956 Rafinesquina pseudoalternata (Schmidt), Jaanusson, pp. 375, $377,379,383$ (named only).

1991 "Rafinesquina" pseudoalternata (Schmidt), Рымусокс, p. 33; Pl. II, fig. 1; Pl. III, figs. 1-4.

Lectotype (here selected). Dorsal valve interior ( $\mathrm{Br}$ 1460), Pl. IV, figs. 1-3 from the Pirgu Stage, Adila Formation. This specimen and three more with good dorsal interiors were collected by Schmidt from the glacial boulders at Vardi, Western Estonia (see Schmidt, 1908, p. 725).

Diagnosis: Large Geniculina with subcircular, almost flat, relatively long ventral disc. Some broad short wrinkles posterolaterally. Ornament with many accentuated costellae and 5-7 finer ones between them at the geniculation. Ventral muscle field relatively small, almost circular, with narrow strong medial ridge. Cardinalia delicate, with thin long medial ridge. Socket plates with well-developed denticles. Muscle field somewhat depressed. Very thin breviseptum. No posterior transmuscle septa.

Remarks. Specimens of G. pseudoalternata from Estonia had never been illustrated before 1991. The original short diagnosis by Schmidt (1858, p. 215) is as follows: "The shell distinctly geniculated. Ornament regular, always $7-8$ fine costellae between the coarser. The ventral interarea higher, the beak with foramen projected posteriorly from hinge line." S. pseudoalternata sensu Schmidt (1858) is thus certainly identical with the specimens in our collections as far as this is the single strophomenacean in the Pirgu Stage with strong, dorsally directed geniculation.

Distribution. Harju Series, Pirgu Stage, Adila Formation with Röa Member (M. Ashgill), North Estonia.

Geniculina sp. n. (PI. IV, fig. 7 in the present article). Boda limestone (Ashgill), Siljan district, Sweden.

\section{Species questionably assigned}

Stropheodonta (Eostropheodonta) helgoeyensis Spjeldnaes, 1957, p. 191; Pl. 12, fig. 6 from the upper part of the Mjøsa Formation (= probably equivalent of the Rakvere Stage of Estonia) (Uppermost Caradoc or L. Ashgill), Norway. Author's examination of the holotype in Paleontologisk Museum, Oslo, shows that it is clearly a species of Geniculina by the features of its cardinalia, particularly with regard to the denticulated socket plates and anterior transmuscle septa. Unfortunately, the interior of the ventral valve is not known. Harper and Boucot $(1978$, p. 102) regarded this species as a leptaenid. It might be the oldest known species of Geniculina.

Rafinesquina pseudoalternata Schmidt in Holtedahl, 1916, p. 21; Pl. III, figs. 9-11 from 5a beds (= Bønsnes Formation), (Ashgill), Norway. Author examined these specimens in the Paleontologisk Museum, Oslo. They should evidently be assigned to a new species of Geniculina which differs from the true $G$. pseudoalternata in having smaller shell and thinner oblique posterolateral wrinkles. Unfortunately no interiors are known.

Discussion. The most characteristic distinguishing features of Geniculina are well-defined but rounded geniculum, almost flat disc on both valves, long trail (the trail is seldom completely preserved), oblique, short 
irregular posterolateral wrinkles, moderately raised bounding ridges of the ventral muscle field and small denticles on the socket plates.

The Baltoscandian species of Geniculina form a closely related group of species, each member of which has a relatively limited stratigraphical range in units from the Oandu to Pirgu stages.

Ventral interior and geniculation of Geniculina resemble those of Mjoesina, proposed by Spjeldnaes in 1957. The systematic status of the latter genus is, however, still somewhat uncertain, because dorsal interior of the type species - Rafinesquina mjoesensis Holtedahl, 1916 - is not known. In spite of this fact, species of Mjoesina have been described by several authors (Spjeldnaes, 1957; Williams, 1962; Mitchell, 1977; Кульков and Севергина, 1989). Emended diagnosis of Mjoesina presented by Williams (1962) was based only on the material from Girvan. He noted that the notothyrial platform and median ridge are faint or absent, socket plates curved and denticulate in adult shells, and the muscle field is generally indistinct. In his description of the new species and subspecies Williams noted that both $M$. rugata and $M$. rugata plana have short rugae posterolaterally, not mentioned in the descriptions of the Norwegian species and in the diagnosis of the genus by Spjeldnaes (1957).

The species of Geniculina described here differ from $M$. rugata Williams, $M$. rugata plana Williams, and $M$. moorei Mitchell in having a large, commonly subcircular ventral muscle field, strongly developed cardinalia, anterior transmuscle septa, high subperipheral rim, and a weaker differentiated sculpture.

Distribution. Upper Caradoc to Ashgill of Baltoscandia, North American Midcontinent Richmondian (Amorphognathus suberbus and A. ordovicicus Conodont Zones).

\section{Acknowledgements}

The author expresses his thanks for kindly help to Professors D. L. Bruton from the Paleontologisk Museum, Oslo, J. Bergström and V. Jaanusson from the Swedish Museum of Natural History, Stockholm, who made it possible in 1991 to examine the strophomenacean collections in these museums. Thanks are due to Dr. R. L. M. Cocks from the British Museum of Natural History for valuable discussions.

\section{REFERENCES}

Bekker, H. 1921. The Kuckers Stage of the Ordovician rocks of N.E. Estonia. - Acta et Comm. Univ. Dorpat. A II.1. Tartu.

Bergström, S. 1971. Conodont Biostratigraphy of the Middle and Upper Ordovician of Europe and Eastern North America. Geol. Soc. Am., Mem. 127, 83-157.

Cooper, G. A. 1956. Chazyan and related brachiopods. - Smiths. Misc. Coll., 127, I. Harper, C. W. and Boucot. A. J. 1978. The Stropheodontacea. Part I. Palaeontographica. Abt. A, Bd. 161, Stuttgart.

Holtedahl, O. 1916. Strophomenidae of the Kristiania Region. - K. Norske Vidensk. Selsk., Skrift, 12. Kristiania.

Jaanusson, V. 1956. Untersuchungen über den oberordovizischen Lyckholm-Stufenkomplex in Estland. - Bull. Geol. Inst. Univ. Uppsala, 36, 369-400.

Jaanusson, V. 1960. The Viruan (Middle Ordovician) of Öland. - Bull. Geol. Inst. Univ. Uppsala, 38, 207-288. 
Lamansky, V. V. 1905. Die ältesten silurische Schichten Russlands. Comité Géol., Mém., new ser., 20. St. Petersburg, 148-203.

Macomber, R. W. 1970. Articulate brachiopods from the Upper Bighorn Formation (Late Ordovician) of Wyoming. - J. Paleont., 44, 3, 416-450.

Mitchell, W. I. 1977. The Ordovician Brachiopoda from Pomeroy, Co. Tyrone. Palaeontogr. Soc. (Monogr.).

Opik, A. 1930. Brachiopoda Protremata der estländischen ordovizischen Kukruse Stufe. Acta et Comm. Univ. Tartu. A XVII.

Pander, C. H. 1830. Beiträge zur Geognosie des Russischen Reiches. St. Petersburg.

Pope, J. K. 1976. Comparative morphology and shell histology of the Ordovician Strophomenacea (Brachiopoda). - Palaeontographica Americana, VIII, 49.

Rõõmusoks, A. 1989. Uber die Divergenz der Leptaenidae (Brachiopoda) in der Viruand Harju-Zeit in Baltoskandia. - Proc. Acad. Sci. Estonian SSR. Geol., 38, 3, $112-117$.

Salmon, E. S. 1942. Mohawkian Rafinesquininae. - J. Paleont., 16, 5, 564-603.

Schmidt, F. 1858. Untersuchungen über die Silurische Formation von Ehstland, NordLivland und Oesel. Arch. Naturk. Liv-, Ehst- u. Kurl., Ser. 1, Bd. 2.

Schmidt, F. 1908. Beitrag zur Kenntniss der ostbaltischen, vorzüglich untersilurischen, Brachiopoden der Gattungen Plectambonites Pand., Leptaena Dalm. und Strophomena Blainv. - Bull. Ac. Imp. Sciences de St. Petersbourg, 717-726.

Spjeldnaes, N. 1957. The Middle Ordovician of the Oslo Region, Norway, 8. Brachiopods of the suborder Strophomenida. - Norsk Geol. Tidsskrift, 37, 1, 1-214.

Wang, Yü. 1949. Maquoketa Brachiopoda of Iowa. - Geol. Soc. America, Mem. 42.

Williams, A. 1962. The Barr and Lower Ardmillian Series (Caradoc) of the Girvan District, south-west Ayrshire, with descriptions of the Brachiopoda. - Geol. Soc. of London Mem., 3.

Williams, A. 1965. Strophomenacea. - In: Moore, R. C. (ed.). Treatise on invertebrate paleontology, H. Brachiopoda. Lawrence.

Алихова Т. Н. 1951. Брахиоподы нижнего силура Ленинградской области и их стратиграфическое значение. ВСЕГЕИ, Москва.

Алихова Т. Н. 1953. Руководящая фауна брахиопод ордовикских отложений северозападной части Русской платформы. ВСЕГЕИ, Москва.

Андреева О. Н. 1961. Strophomenida. - In: Биостратиграфия палеозоя Сибирской платформы. Ленинград, 69-193.

Кульков Н. Т., Севергина Л. Г. 1989. Стратиграфия и брахиоподы ордовика и нижнего силура Горного Алтая. - Тр. Ин-та геологии и геофизики Сибирского отд-ния АН СССР, 717. Москва.

Рыbмусокс A. 1991. О стратиграфии и фауне пограничных слоев пиргуского и поркуниского горизонтов в Северной Эстонии. - Acta et Comm. Univ. Tartuensis, 934. Tartu, $23-42$.

Сокольская А. Н. 1954. Строфомениды Русской платформы. - Тр. Палеонтол. ин-та АН СССР, 51. Москва.

Сокольская A. H. 1960. Отряд Strophomenida. - In: Основы палеонтологии. Мшанки и брахиоподы. Москва. 


\section{NELI UUT BRAHHIOPOODI PEREKONDA ALAMSUGGKONNAST OEPIKINAE (STROPHOMENACEA) EESTI ORDOVIITSIUMIST}

On kirjeldatud uusi perekondi Panderites, Tallinnites, Bekkerina (koos ühe uue liigiga) ja Geniculina. Baltoskandia ordoviitsiumi vanim öpikiniid on Panderites sp. Kunda lademest. Perekonda Bekkerina kuuluvad liigid, mida seni tavaliselt peeti perekonda Oepikina kuuluvaks.

Арво РЫЫМУСОКС

\section{ЧЕТЫРЕ НОВЫХ РОДА БРАХИОПОД ПОДСЕМЕИСТВА ОЕРІКІNАЕ (STROРНОМЕNACEA) ИЗ ОРДОВИКА ЭСТОНИИ}

Дано описание новых родов Panderites, Tallinnites, Bekkerina (с одним новым видом) и Geniculina. Древнейшим представителем Oеpikinae в ордовике Балтоскандии является Panderites sp. из кундаского горизонта. K роду Bekkerina отнесены виды, которые до сих пор причисляли к роду Oepikina. 